\title{
Nursing practice in the promotion of the elderly's autonomy
}

\author{
Prática de enfermagem na promoção da autonomia dos idosos \\ Práctica de enfermería en la promoción de la autonomía de los ancianos
}

How to cite this article:

Lima AMN, Martins MMFS, Ferreira MSM, Coelho ARN, Schoeller SD, Parola VSO. Nursing practice in the promotion of the elderly's autonomy. Rev Esc Enferm USP. 2021;55:e20210029. DOI: https://doi.org/10.1590/1980-220X-REEUSP-2021-0029

\section{iD Andreia Maria Novo Lima ${ }^{1}$ \\ iD Maria Manuela Ferreira da Silva Martins ${ }^{2}$ \\ Maria Salomé Martins Ferreira ${ }^{3}$ \\ Adriana Raquel Neves Coelho ${ }^{4,5}$ \\ Soraia Dornelles Schoeller ${ }^{6}$ \\ D Vítor Sérgio Oliveira Parola ${ }^{4,5}$}

${ }^{1}$ Instituto de Ciências Biomédicas Abel Salazar, Porto, Portugal, Escola Superior de Saúde da Universidade Fernando Pessoa, Porto, Portugal.

${ }^{2}$ Escola Superior de Enfermagem do Porto CINTESIS, Porto, Portugal.

${ }^{3}$ Instituto Politécnico de Viana do Castelo, Escola Superior de Saúde - Viana do Castelo, Unidade de Investigação em Ciências da Saúde:

Enfermagem, Núcleo da Escola Superior

de Saúde, Instituto Politécnico de Viana do

Castelo, Viana do Castelo, Portugal.

${ }^{4}$ Escola Superior de Enfermagem de Coimbra, Coimbra, Portugal, Unidade de Investigação em Ciências da Saúde: Enfermagem, Coimbra, Portugal.

${ }^{5}$ Centro de Prática Baseada em Evidencias:

Um Centro de Excelência do Instituto Joanna Briggs, Coimbra, Portugal.

${ }^{6}$ Universidade Federal de Santa Catarina,

Florianópolis, SC, Brazil.

\begin{abstract}
Objective: To describe the meaning attributed by specialist nurses to the promotion of the elderly's autonomy. Method: This is a phenomenological study, according to Giorgi's method, which uses semi-structured interviews. Eighteen specialist nurses participated, recruited using convenience sampling, in two hospitals in the northern region of Portugal, between March and December 2018. Results: Five themes emerged: use of instruments; use of theoretical framework; nursing diagnoses; prescription of interventions; nursing records. Conclusion: Specialist nurses use instruments that essentially promote the elderly's physical capacity, within the scope of autonomy. The information systems used to record the diagnoses and prescriptions for interventions do not reflect the intervention for the person's autonomy. Autonomy in a multidimensional way is not very well developed, despite the recognition of its importance for the elderly's quality of life and dignity.
\end{abstract}

\section{DESCRIPTORS}

Patient Care; Nursing Diagnosis; Nursing Care; Personal Autonomy; Qualitative Research; Geriatric Nursing. 


\section{INTRODUCTION}

Demographic aging is a worldwide phenomenon, and it is associated with the growing prevalence of chronic and debilitating diseases that affect the elderly. These diseases put not only mobility into question, but also the subject's autonomy ${ }^{(1,2)}$.

In the context of provision of nursing care, it is common to daily hear the speeches of most professionals on the term autonomy relating it with the subject's physical independence. With regard to the prescription of nursing interventions aimed at the promotion/maintenance of the person being cared for, when checked on practice, they refer to the promotion of independence, especially with regard to the physical condition ${ }^{(3)}$.

The care provided to the elderly population requires nurses' change in attitudes and behavior, as these professionals shall be aware of all the dimensions that the concept of autonomy encompasses ${ }^{(4)}$. The clinical interview and the careful and systematic observation allow the recognition of problems, the elaboration of diagnoses, and the planning of care for an adequate response to the needs of the person being cared for ${ }^{(5-7)}$.

In clinical practice, it is observed that, in the nursing processes developed, the subject's autonomy is set apart, as professionals direct care to the person's physical independence in activities of daily living ${ }^{(3)}$, designating this type of interventions as promoters of autonomy; here lies the relevance of the present study.

In the various disciplines of knowledge, the importance of a person's autonomy is recognized, especially with regard to its aspects. Quality of life depends directly on autonomy, as it is supported by the person's dignity and integrity, resorting to the right to self-determination ${ }^{(8)}$.

Autonomy is driven by an intrinsic source of motivation to control the own destiny, dominate life and behavior, using the theory of self-determination ${ }^{(9)}$; it is the freedom of choice and the ability to control actions ${ }^{(10)}$. The theory of self-determination focuses on three constructions, namely: autonomy, in which the person expresses the desire to be the origin of their own behavior, with no interference of other people; competence, in which the person's expressed need to feel effective in carrying out their actions takes place; and finally, relationship, which comprises the desire to feel connected to one's social group and the community, and to be valued by them ${ }^{(11)}$.

The concept of autonomy comprises several dimensions: biological, social, psychological, and spiritual, with the integration of all these ${ }^{(12)}$ being essential, especially when one intends to diagnose, prescribe, and evaluate interventions in the nursing profession ${ }^{(2,5)}$.

Most professionals focus more on the legal aspects such as protecting a right and, consequently, fulfilling a duty - than on the personal and subjective aspects arising from people's ability to deliberate autonomously about their own lives. Hence the need to understand, in the speeches of specialist nurses, the way in which autonomy in clinical practice is worked ${ }^{(13)}$ is highlighted.
The significant increase in population is a reality in Portugal, as in most European countries. This tendency highlights the problems related to aging and leads to some concern regarding the living conditions and health-disease processes of older people ${ }^{(5)}$. Thus, respect for autonomy becomes particularly important for the elderly, as the processes resulting from aging place the person in a situation of not only physical, but also intellectual and cognitive vulnerability ${ }^{(6,7,14)}$.

Changing the culture of elderly care within the scope of autonomy is a challenge, as nurses recognize and demonstrate the application of care routines, and that is why the implementation of work and training measures and methodologies for these professionals is required. Reflecting on practices is the first step towards change, when it becomes necessary.

Considering the above, in this study the research question was: What is the meaning of the clinical experience lived by specialist nurses regarding the promotion of the elderly's autonomy?

The following objective was defined: to describe the meaning attributed by specialist nurses to the promotion of the elderly's autonomy.

\section{METHOD}

\section{Type Of Study}

This is a study with a qualitative approach, using the phenomenological method. Phenomenology aims to describe a phenomenon through the sense and meaning people attribute to their experiences, relying on its analysis ${ }^{(15)}$.

The methodological orientation used was the phenomenological analysis by Giorgi ${ }^{(16)}$, whose objective is to search for the meanings of human action through its analysis and comprehension.

All interviews were audio-recorded and transcribed in full, and were carried out by the same investigator.

Finally, to obtain confirmation/confirmability, the interviews were all carried out by the first author, who does not work in any of the health institutions where data were collected, and had no connection with the participants.

Place

Two health institutions located in the north of Portugal were selected: a medium-sized general hospital, with about 180 beds and one intensive care unit; and, a large and highly complex General Hospital, which is a reference in the region.

\section{Population}

Eighteen specialist nurses, who work in internal medicine, surgery, and orthopedics units, participated in this study. Participants were appointed by the managing nurses of each unit.

\section{Selection Criteria}

The inclusion criteria were: at least 6 months of work with the elderly at the place, to be a specialist in Rehabilitation 
Nursing and/or Medical-Surgical Nursing, and/or Mental Health Nursing and Psychiatry and/or Community Nursing, and to develop their professional activity in direct assistance. In Portugal, there is not the specialty of Gerontology, and this is why the nurses indicated for the study were those developing care actions for the elderly. All generalist nurses, specialist nurses in Child Health Nursing and Pediatrics and Maternal and Obstetric Health Nursing were excluded.

\section{Data Collection}

The present study adhered to credibility, consistency, transferability, and confirmability to support the rigor of the scientific quality of qualitative research ${ }^{(17)}$.

For credibility, during the interviews, clarifications and confirmations were made about the information mentioned by the participants. The interviewer was a doctoral student, supervised by a Ph.D. in nursing.

Consistency was achieved through the description of the participants' characteristics, the selection process, and the description of the research steps and results. The second author also carried out individual analyses to give rigor to the process.

A detailed description of the participants' characteristics and the study context was provided, so that readers can determine if the results obtained can be transferred (transferability) to another context.

The instrument for data collection consisted of two parts: a sociodemographic questionnaire to characterize the participants and a semi-structured interview script with open questions aimed at reporting professional experience. All interviews started with the following question: Given your experience, how do you experience the process of promoting autonomy in the care you provide to the elderly? To better understand the participants' experience, other questions were asked: Can you describe this experience in more detail, was this experience meaningful to you? The interviews were carried out between March and December 2018 and the average duration was 30 minutes. Contact with the participants was previously carried out, with the collaboration of the head nurses of the respective services where the nurses worked. None of the participants refused/ quit from participating in the study. A pilot interview was previously carried out, which was not included in the study. The interviews were conducted in person, being recorded and later transcribed by the interviewer. During the interviews, field notes were made.

\section{Data Analysis and Treatment}

Data analysis was performed after the interviews transcription, according to Giorgi's method: 1) get the meaning of the whole: repeated reading of the transcripts to get a general idea of the lived experience; 2) discrimination of the units of meaning: the transcribed interviews were re-read over a long period of time, and when a transition of meaning was identified in the transcripts, these were marked as relevant aspects of the phenomenon under investigation. From this step, a series of units of meaning were obtained, still expressed in the common language of the participants; 3) transformation of the common language of the meaning units into scientific language: the meaning units were rewritten in a language appropriate to the phenomenon under study, remaining faithful to the meanings expressed by the participants. This imaginative variation allowed us to determine the essence of the phenomenon's structure; and 4) synthesis of the meaning units transformed into a descriptive structure of the experience lived by the participants $^{(16)}$.

Atlas.ti software version 8.4 was used to systematize and catalog the analyzed material. The data obtained were coded with the letter "E" and each participant was given a number.

\section{Ethical Aspects}

The research project was assessed by the ethics committees of both health institutions, which issued favorable opinions (no.324/17 and no. 11/18). Authorization was also granted by both institutions' Boards of Directors where the data were collected. In the scope of the application of the data collection instruments, all ethical procedures were followed, through the signing of the Informed Consent Form, giving participants the necessary information and ensuring confidentiality and anonymity. This study complies with the Consolidated Criteria for Qualitative Research Reports (COREQ) ${ }^{(18)}$ guidelines.

\section{RESULTS}

Participants Characterization:

Most participants are women (94.4\%). The mean age is 39.6 years; on average they have been working for 16.3 years and have been specialists for 5.9 years; most are specialist nurses in rehabilitation nursing $(77.7 \%)$, followed by $11.1 \%$ of specialist nurses in community nursing, and the same percentage of specialists in medical-surgical nursing.

From data analysis, five themes emerged, reflecting the essence of the experiences of specialist nurses in promoting/ maintaining the autonomy of the elderly: 1) use of instruments, 2) use of theoretical framework, 3) nursing diagnosis, 4) prescription of interventions and 5) nursing records, described in Figure 1.

\section{USE OF INSTRUMENTS}

Most participants recognize that they do not use instruments that measure autonomy, No... I don't even know any (E9), since these, covering all the dimensions mentioned ${ }^{(12)}$, do not exist.

Others mentioned that to assess autonomy they use scales such as the Functional Independence Measure (FIM), Lawton scale, and Barthel scale, as can be seen in their statements: (...) I've already used FIM, but at this moment we only used Barthel scale (E1) and we used Lawton scale and Barthel scale (E6).

Specialist nurses who mention the use of these tools recognize the disadvantages of the instruments they use, noting that they are very limited and do not measure all dimensions of the person's autonomy, (...) FIM can only assess 


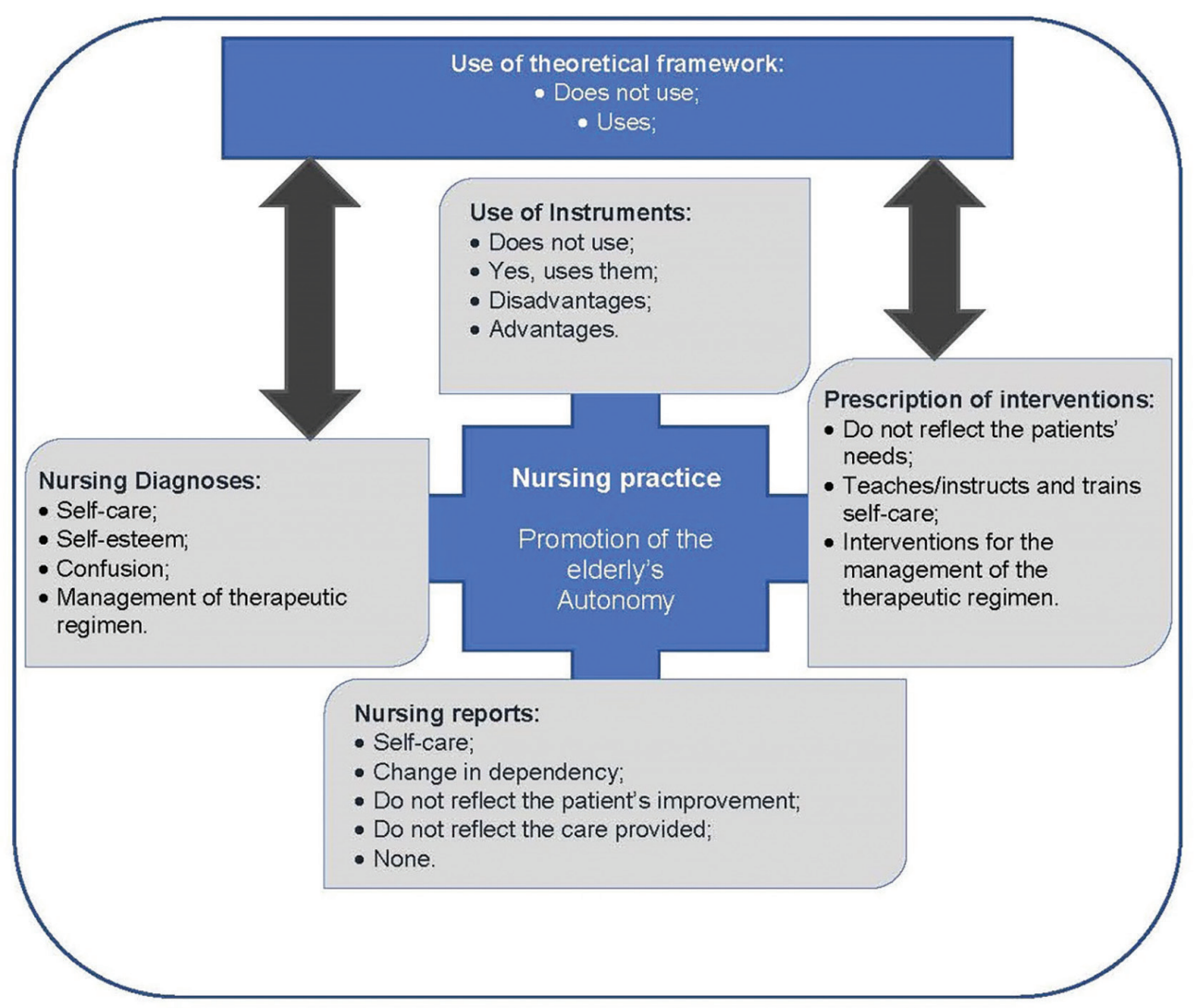

Figure 1 - Empirical Structure of the Phenomenon Analysis.

the physical part, the cognitive part and also mentions the social part, but it is limited when we want to assess autonomy, which in my opinion is much more than that (E1). In their speeches, the nurses also report that Barthel scale only assesses the physical part; therefore, for me, it is not able to assess autonomy (E1) and it is very limited, it only assesses people's capacities for activities of daily living (E6).

Lawton scale is also mentioned by the participants; however, in their opinion this (...) is not very well adjusted in terms of hospitalization. It is much valid for primary health care (E6).

The participants highlighted the advantages of these instruments, and recognized that, with their use, it is possible to perceive... the patient's progression (E17) and allowing to know (...) health gains, from the moment they entered the unit, after rehabilitation, until the moment they left (E17).

\section{Use of Theoretical Framework}

Participants assumed consciously not using any theory: (...) I don't use any in concrete (E1), I'll be honest... theories, I've already known them, I've already...I've studied this throughout the nursing course, the specialty course... and now in practice I'm sure I must be using some, of course, but now names... (E14) and I don't have any particular theory that I base myself on in practice... I know all theories...even from my recent training... but I don't base myself on any one concretely (E17).

However, some of the nurses emphasize in their speeches: (...) I drink a little of each theory to provide care, according to what I consider correct and necessary for the patients (E1). Others highlight references such as Jean Watson, or Orem, stating: (...) there are some references that I like as a person... Watson and her care process is very important to me... regarding self-care, Orem (E2).

\section{Nursing Diagnoses}

In the speeches, self-care is highlighted, essentially because the professionals relate autonomy to these aspects, namely, eating, using the toilet, personal hygiene, positioning, walking, and transferring, as shown by their speeches: (...) autonomy to wash, autonomy to eat, autonomy to go to the toilet, impaired walking ability (E2).

Other diagnoses, such as self-esteem, are mentioned in the specialist nurses' speeches: (...) autonomy is also the ability to believe that I am capable of doing it (E29); confusion, it is highlighted in the speeches at the cognitive level, really... only when the patient is confused, we use confusion (E18) and confusion: ... we sometimes open it up for nurses to know that the patient is confused (E18).

Professionals also show that they use the diagnosis of therapeutic regimen management: (...) management of the therapeutic regimen, this is clear to prepare the patient for discharge (E1).

\section{PRESCRIPTION OF INTERVENTIONS}

Specialist nurses report that they prescribe, within the scope of autonomy, interventions to teach, instruct and train 
in self-care and therapeutic regimen management interventions: (...) I use all interventions that instruct/teach and train self-care (E16), highlighting that the prescriptions of interventions that are parameterized in the information systems, with regard to autonomy, are those already referenced, that is, in the context of self-care, of self-esteem, confusion, and management of the therapeutic regimen, when they say: (...) we no longer have interventions that we see that are parameterized to work on autonomy (E1).

\section{Nursing ReCORdS}

Regarding self-care, specialist nurses report that they record: (...) only in relation to self-care (E1), we focus more on self-care (E4) and everything is related to self-care (E6).

They also point out that the patient's progression is manifested through the change in dependence: (...) specifically and when we manage to update the plans, then we try as much as possible to express an improvement in autonomy or of a deficit (E5) and we end up doing it, in the sense of... if I have a patient who is classified as totally dependent... I have an intervention in self-care... bathing in bed... when this patient shows any change, helshe starts being able to collaborate a little bit and I go, in computer terms, change the degree of dependence to a moderate degree... this will demonstrate that there is an improvement in terms of self-care and, consequently, in the patient's autonomy (E6).

Some professionals report that the records made do not reflect the patient's improvement, as noted: (...) they say nothing about the improvement of the patient's condition (E1) and (are) insufficient, inadequate, very dispersed and not very concrete (E2).

It is consensual for nurses that the records do not reflect the care provided: (...) they only refer to self-care interventions we do, which is very little or nothing (E5), and unfortunately we end up losing a lot of information that should be recorded, but it is very difficult to do that. We failed a lot in this area of records (E10).

Professionals report that regarding autonomy, they do not record it: None (E1).

\section{DISCUSSION}

The sample sociodemographic and professional data corroborate the data from the Portuguese Nurses' Association $^{(19)}$, in which most nurses are women, the age groups that comprise the largest number of nurses are between 31 and 35 and 36 to 40 years old, with 13,607 and 13,164 nurses, respectively, with most of them also being specialist nurses in Rehabilitation Nursing. Professional experience is one of the essential aspects for effective and efficient management and decision-making, allowing the realization and enhancement of knowledge and evidencebased practice, aiming at the continuous improvement of the care provided.

The instruments are used to measure certain aspects, and have been essential tools that allow health professionals to perceive effective health gains and collaborate, together with clinical assessment, to identify problems or potential problems ${ }^{(20)}$. However, these should not be seen as unique tools. Rather, they shall be used in conjunction with clinical assessment, which the nurse's body of knowledge allows them to carry out.

This study led to the comprehension that there is some confusion in the specialist nurses' discourse, as the instruments mentioned do not assess autonomy, but independence, as highlighted by other authors in their study ${ }^{(3)}$. When they address autonomy and when they report that they use assessment instruments, it appears that the instruments reported allow the assessment of the person's ability to perform basic activities of daily living (Barthel Scale) and instrumental activities of daily living (Lawton scale). FIM, besides the basic activities of daily living, includes other aspects covered by the concept of autonomy, such as cognition and social integration ${ }^{(11,12,14)}$; however, it does not refer to intelligence management, as the authors point out in their study ${ }^{(4)}$.

Although there is some confusion about the integrity of the concept of autonomy and its scope, some of the specialist nurses, through their discourse on the use of these instruments as a way to assess the autonomy of the elderly, recognize the disadvantages of the instruments they use, noting that they are very limited and do not measure all dimensions of a person's autonomy. These results corroborate those of other authors ${ }^{(4,12)}$. Within the scope of the concept of autonomy, the instruments referred to as being used in their clinical practice and which they mention as contributing to the understanding of the degree of autonomy of the elderly, such as Barthel Scale, FIM and Lawton Scale, only respond to physical capacity; thus, the participants' speeches show that they express a concern about the person's autonomy in this physical dimension, not exploring the other dimensions of the person's autonomy. The results obtained in this study corroborate the evidence available, which shows that the physical dimension is emphasized to the detriment of other dimensions ${ }^{(3)}$. Based on the Self-Determination Theory, these professionals value competence more than the other aspects this theory addresses, namely autonomy and relationship ${ }^{(11)}$.

Nursing professionals are daily challenged to improve and maintain their bases founded on the profession of caring $^{(13)}$. However, in recent years, we have witnessed an intrinsic duality in the nursing profession, in which theory and practice are seen as two different realities, which causes some confusion in nurses, who admit that theoretical frameworks have little relevance to clinical practice ${ }^{(21)}$. Although specialist nurses refer to the knowledge and importance of theoretical frameworks in their speeches, they express that they do not apply them in their professional practice, using their professional experience, intuition, critical thinking, and evidence-based practice as sources for decision-making, corroborating the results obtained in another study ${ }^{(21)}$.

The lack of these references can lead to a culture centered essentially on the disease, and consolidated in the biomedical model, where the role of the nurse is focused only on the management of symptoms and signs ${ }^{(22)}$. Since nursing is 
a science with its own body of knowledge, also based on nursing theories, which serve as guidelines for care, it is critical that nurses be guided by this knowledge, and it is essential to eliminate the distance between theory and practice, through the approximation of academic and professional contexts ${ }^{(21)}$.

Watson's theory assumptions consider a humanist view of being cared for, through an educational interaction between the professional and the person cared for ${ }^{(13)}$. This interaction favors the active participation of the person cared for in decision-making, consequently respecting the ethical principles of the profession and promoting the processes arising from autonomy ${ }^{(23)}$. With no disciplinary guidance, it is easy to lose control ${ }^{(13)}$ and fall into the temptation to base nursing care on the biomedical model ${ }^{(22)}$.

The assessment of the elderly's autonomy, in the entirety of this concept, shall be carried out aiming at identifying problems or possible problems, such as a multidimensional assessment that may include cognition, emotional management, social and environmental aspects that interfere with their autonomy ${ }^{(4,12)}$. As a whole, this assessment shall consider all aspects that the Self-Determination Theory covers, such as autonomy, competence and relationship ${ }^{(11)}$. In this context, autonomy comprises the ability to decide, through intact intellectual capacity and empowerment in health. On the other hand, the relationship includes the person's ability to integrate socially, recognizing that they can only be autonomous if they are integrated in the environment in which they are inserted ${ }^{(4,12)}$.

In the present study, when participants mention diagnoses they use, as responding to the needs in the context of autonomy, they highlight those aimed at self-care, thus valuing competence. However, through these, independence is worked, and this shows that autonomy is not considered in its entirety. These findings reinforce the evidence available ${ }^{(3)}$. To work on autonomy, in the true essence of the concept, other diagnoses shall be considered, and respond to the dimensions described by the evidence ${ }^{(4,12)}$.

Self-esteem, also referenced by specialist nurses, may constitute a nursing diagnosis that, when worked, may be reflected in skills required to live an autonomous life, responding to cognition and emotional management, as defended by the evidence ${ }^{(5)}$, but this is identified only when there is a problem.

The diagnosis of confusion is also referenced, since part of elderly people hospitalized, due to aspects resulting from aging and disease processes, present confusional conditions resulting from alterations, which can range from mild to severe $^{(14)}$. In confusional conditions, when one reaches for cognitive stimulation programs, an attempt is made to respond to the training of the elderly, in the cognitive aspect, with regard to the promotion of autonomy ${ }^{(5,24)}$.

The diagnosis of the therapeutic regimen management allows turning the nurse's attention to the development of skills to deal with health issues and life in general, promoting health literacy, an essential factor for promoting autonomy ${ }^{(20)}$.

The prescription of interventions is a step in the nursing process, and refers to the planning of nursing interventions.
This planning is useful for clinical documentation, for passing on information, and systematizing care.

Although nurses show that they prescribe teaching- and instructing-like interventions, these were not associated with any diagnosis taking knowledge as a dimension; similarly, for instructing- and training-like interventions, they also do not refer to diagnoses taking skills or abilities as dimensions, according to the version of the International Classification for Nursing Practice (ICNP) used by the institution ${ }^{(25)}$.

Its identification through diagnosis and subsequent assessment is essential, since to teach, instruct and train, the person needs to demonstrate awareness, volition, and abilities to improve. As it is not possible to learn without these skills, even if these interventions are implemented, failure is certain in these cases ${ }^{(20)}$.

The specialist nurses' speeches make clear that institutionalized information systems are not adequate, as they do not allow to reflect the needs of the person being cared for, and consequently, the care provided ${ }^{(24)}$. However, these tools cannot be confused with a good practice manual ${ }^{(25)}$.

Health literacy, measured through interventions related to teaching, depends on cognitive and social skills, highlighted by the Theory of Self-Determination ${ }^{(11)}$, and, once these skills are assured, the person is in the expected condition, for well-founded decision-making and being capable of maintaining their health and, consequently, quality of life throughout the life cycle ${ }^{(20)}$.

Also regarding the nursing records made, similarly to the diagnoses and nursing interventions performed, within the scope of autonomy, they are based on self-care, as they aim to describe the care provided, corroborating the results of studies by other authors ${ }^{(3,24)}$.

Changes in the dependency status are considered by professionals as nursing records, but they recognize that they do not always do them. Health gains can only be reproduced through effective and systematic records, as well as through the use of instruments that measure these same gains, as highlighted by the authors ${ }^{(20)}$.

For various reasons, the elderly's autonomy in the nursing process is set apart, even though some nurses report that they implement more nursing interventions than those that they prescribe and register. However, these same interventions, due to lack of planning, end up not being continued, as desired in the nursing process, and by the underlying theories of nursing practice ${ }^{(13)}$.

According to the Self-Determination Theory, autonomy is a psychological construction, in which the person expresses the desire to be the origin of their behavior, with no interference of third parties; however, for autonomy, the person needs to have skills, both in the capacity to perform the tasks, and in the relationship with other people, with the society ${ }^{(26,27,28)}$. In clinical practice, this distinction is ambiguous, and professionals attribute these meanings to the concept of autonomy, as can be seen in a previously conducted study ${ }^{(4)}$. In the concept analysis carried out ${ }^{(4)}$, autonomy comprises: physical capacity, cognitive capacity, emotional intelligence, and social integration, which somehow responds to the theory of self-determination, also 
expressing the emotional management capacity, essential to the manifestation of autonomy.

Regarding the limitations of the present study, they involve the absence of specialist nurses in the field of mental health, which could mean more quality to notice if their practices add value in promoting/maintaining the elderly's autonomy, as these professionals direct their care towards the promotion of cognition. Another limitation refers to the absence of nurses in the gerontology and geriatrics nursing area, as this is the specialty with knowledge to assess the aging process and the importance of autonomy in the elderly's quality of life. Therefore, it would be interesting to include nursing professionals trained in the field of gerontology in the study; however, this is not yet considered a specialization in Portugal, and there are still few professionals with graduate certificates and master's degree in this area. In view of population aging, the need for investment in training is perceived, as well as for the recognition of these professionals with a view to obtaining optimal care.

\section{CONCLUSION}

The results of this investigation show that the concept of autonomy for specialist nurses is very much directed towards the physical dimension, as they refer to the use of instruments that measure this dimension; however, they recognize that they have limitations. Through their speeches, when nurses intend to explain autonomy, they mention the importance of theoretical frameworks. However, when asked about their use, they report that they do not use them consciously in their practice. In clinical practice, they use diagnoses, prescribe interventions, and make nursing records, which seek to respond to their concerns in the context of promoting the elderly's autonomy, but do not do so.

The phenomenological method, due to its potential for participation and reflection, allows for the expansion of knowledge about nursing practices. Thus, this study allowed understanding how nurses in clinical practice act regarding the elderly's autonomy.

Noticing, in this study, through the instruments used, the prescribed nursing diagnoses and interventions, and the records made, that the focus of the concept of autonomy is on the physical dimension, it is essential that future studies seek the development of an instrument with an holistic view of the various dimensions. It is equally critical that these health professionals reflect on their clinical practice and direct their care towards interventions that promote the elderly's autonomy, through the implementation of programs that can contribute to healthy and successful aging.

\section{RESUMO}

Objetivo: Descrever o significado atribuído por enfermeiros especialistas à promoção da autonomia dos idosos. Método: Estudo fenomenológico, segundo o método de Giorgi, que recorre à entrevista semiestruturada. Participaram 18 enfermeiros especialistas, recrutados por conveniência em dois hospitais da região a norte de Portugal, entre março a dezembro de 2018. Resultados: Emergiram cinco temas: uso de instrumentos; uso de referencial teórico; diagnósticos de enfermagem; prescrição de intervenções; registros de enfermagem. Conclusão: Os enfermeiros especialistas utilizam instrumentos que promovem essencialmente a capacidade física dos idosos, no âmbito da autonomia. Os sistemas de informação utilizados para registrar os diagnósticos e prescrições de intervenções não refletem a intervenção para a autonomia da pessoa. A autonomia de forma multidimensional é pouco trabalhada, apesar do reconhecimento de sua importância para a qualidade de vida e dignidade da pessoa idosa.

\section{DESCRITORES}

Assistência ao Paciente; Diagnóstico de Enfermagem; Cuidados de Enfermagem, Autonomia Pessoal; Pesquisa Qualitativa; Enfermagem Geriátrica.

\section{RESUMEN}

Objetivo: Describir el significado atribuido por enfermeros expertos sobre la promoción de la autonomía de los ancianos. Método: Estudio fenomenológico, según el método de Giorgi, basado en entrevista semiestructurada. Participaron 18 enfermeros expertos, convocados por conveniencia en dos hospitales en una región al norte de Portugal, entre marzo y diciembre de 2018. Resultados: Surgieron cinco temas: uso de instrumentos; uso de referencias teóricas; diagnósticos de enfermería; prescripción de intervenciones; registros de enfermería. Consideraciones Finales: Los enfermeros expertos utilizan instrumentos que promueven esencialmente la capacidad física de los ancianos en lo que se refiere a la autonomía. Los sistemas de información utilizados para registrar los diagnósticos y prescripciones de intervenciones no reflejan la intervención para la autonomía de uno. La autonomía de forma multidimensional se ha trabajado poco, a pesar del reconocimiento de su importancia para la calidad de vida y dignidad del anciano.

\section{DESCRIPTORES}

Atención al Paciente; Diagnóstico de Enfermería; Atención de Enfermería; Autonomía Personal; Investigación Cualitativa; Enfermería Geriátrica.

\section{REFERENCES}

1. Instituto Nacional de Estatística. Projeções de População Residente [dataset on the internet]. Lisboa: INE; 2017 Mar 29 [cited 2020 Jan 14]. Available from: https://www.ine.pt/xportal/xmain?xpid=INE\&xpgid=ine_destaques\&DESTAQUESdest_boui=277695619\&DESTAQ UESmodo $=2 \&$ xlang $=$ pt.

2. Cruz AG, Gomes AMT, Parreira PMSD. Focos de atenção prioritários e ações de enfermagem dirigidos à pessoa idosa em contexto clínico agudo. Revista de Enfermagem Referência. 2017; Série IV(15):73-82. DOI: http://dx.doi.org/10.12707/RIV17048.

3. Bennett L, Bergin M, Wells JSG. The social space of empowerment within epilepsy services: The map is not the terrain. Epilepsy \& Behavior. 2016;56:139-48. DOI: http://dx.doi.org/10.1016/j.yebeh.2015.12.045.

4. Lima AMN, Martins MM, Ferreira MS, Schoeller S, Parola VS. O conceito multidimensional de autonomia: uma análise conceptual recorrendo a uma scoping review. Revista de Enfermagem Referência. Forthcoming 2021. 
5. Passos J, Sequeira C, Fernandes L. Focos de enfermagem em pessoas mais velhas com problemas de saúde mental. Revista de Enfermagem Referência. 2014;Série IV(2):81-91. DOI: http://dx.doi.org/10.12707/RIV14002.

6. Apóstolo J, Cooke R, Bobrowicz-Campos E, Santana S, Marcucci M, Cano A, et al. Effectiveness of interventions to prevent pre-frailty and frailty progression in older adults: a systematic review. JBI Database System Rev Implement Rep. 2018;16(1):140-232. DOI: http://dx.doi. org/10.11124/jbisrir-2017-003382.

7. Apóstolo J, Cooke R, Bobrowicz-Campos E, Santana S, Marcucci M, Cano A, et al. Predicting risk and outcomes for frail older adults: an umbrella review of frailty screening tools. JBI Database System Rev Implement Rep. 2017;15(4):1154-208. DOI: http://dx.doi.org/10.11124/ jbisrir-2016-003018.

8. Delmar C. The interplay between autonomy and dignity: summarizing patients voices. Med Health Care Philos. 2013;16(4):975-81. DOI: http://dx.doi.org/10.1007/s11019-012-9416-6.

9. Eassey D, Smith L, Reddel HK, Ryan K. The impact of severe asthma on patients' autonomy: A qualitative study. Health Expectations. 2019;22(3):528-36. DOI: http://dx.doi.org/10.1111/hex.12879.

10. Reach G. Adherence challenges in chronic diseases. Medecine des Maladies Metaboliques. 2018;12(6):511-5. DOI: http://dx.doi. org/10.1016/S1957-2557(18)30135-4.

11. Fu HNC, Adam TJ, Konstan JA, Wolfson JA, Clancy TR, Wyman JF. Influence of patient characteristics and psychological needs on diabetes mobile app usability in adults with type 1 or type 2 diabetes: Crossover randomized trial. Journal of Medical Internet Research. 2019;21(4). DOI: http://dx.doi.org/10.2196/11462.

12. Trotter G. Autonomy as self-sovereignty. HEC Forum. 2014;26(3):237-55. DOI: http://dx.doi.org/10.1007/s10730-014-9248-2

13. Watson J. Elucidando a disciplina de enfermagem como fundamental para o desenvolvimento da enfermagem profissional. Texto \& Contexto Enfermagem. 2017;26(4). DOI: http://dx.doi.org/10.1590/0104-07072017002017editorial4.

14. Lima AMN, Ferreira MSM, Martins MMPS, Fernandes CS, Moreira MTF, Rodrigues TMP. Independência funcional e o estado confusional de pessoas sujeitas a programa de reabilitação. Journal Health NPEPS. 2020;5(2):145-60. DOI: http://dx.doi.org/10.30681/252610104440.

15. Streubert H, Carpenter DR. Investigação Qualitativa em Enfermagem - Avançando o Imperativo Humanista. 5th ed. Loures: Lusodidacta; 2013.

16. Giorgi A. An affirmation of the phenomenological psychological descriptive method: A response to Rennie. Psychological Methods. 2014;19(4):542-51. DOI: http://dx.doi.org/10.1037/met0000015.

17. Lincoln YS, Guba EG. Naturalistic Inquiry. Newbury Park: Sage Publications; 1985.

18. Tong A, Sainsbury P, Craig J. Consolidated criteria for reporting qualitative research (COREQ): a 32 -item checklist for interviews and focus groups. International Journal for Quality in Health Care. 2007;19(6):349-57. DOI: http://dx.doi.org/10.1093/intqhc/mzm042.

19. Ordem dos Enfermeiros. Anuário Estatístico de 2019. Lisboa: Ordem dos Enfermeiros; 2020. Available from: https://www.ordemenfermeiros. pt/arquivo/estatistica/2019_AnuarioEstatisticos.pdf.

20. Direção Geral de Saúde. Manual de Boas Práticas Literacia em Saúde - Capacitação dos Profissionais de Saúde [dataset on the internet]. Lisboa: DGS; 2019 Oct 18 [cited 2020 Jan 14]. Available from: https://www.dgs.pt/documentos-e-publicacoes/manual-de-boas-praticasliteracia-em-saude-capacitacao-dos-profissionais-de-saude-pdf.aspx.

21. Ribeiro O, Martins MMPS, Tronchin DMR, Silva JMAV. Exercício profissional dos enfermeiros sustentado nos referenciais teóricos da disciplina: realidade ou utopia. Revista de Enfermagem Referência. 2018;Série IV(19):39-48. DOI: http://dx.doi.org/10.12707/RIV18040.

22. Sousa MRMGC, Martins T, Pereira F. O refletir das práticas dos enfermeiros na abordagem à pessoa com doença crónica. Revista de Enfermagem Referência. 2015;Série IV(6):55.63. DOI: http://dx.doi.org/10.12707/RIV14069.

23. Savieto RM, Leão ER. Assistência em Enfermagem e Jean Watson: Uma reflexão sobre a empatia. Esc Anna Nery. 2016;1(20):198-202. DOI: http://dx.doi.org/10.5935/1414-8145.20160026.

24. Lira LN, Santos SSC, Vidal DAS, Gautério DP, Tomaschewski-Barlem JG, Peiexak DR. Diagnósticos e prescrições de enfermagem para idosos em situação hospitalar. Avances en enfermería. 2015;33(2):251-60. DOI: http://dx.doi.org/10.15446/av.enferm.v33n2.30762.

25. Paiva A, Cardoso A, Sequeira C, Morais EJ, Bastos F, Pereira F, et al. Análise da parametrização nacional do Sistema de Apoio à Prática de Enfermagem - SAPE 2014. [internet]. 1st ed. Porto: ESEP; 2014 [cited 2020 Jan 14]. Available from: https://www.esenf.pt/fotos/editor2/i_d/ publicacoes/apn-978-989-98443-5-3.pdf.

26. Eassey D, Smith L, Reddel HK, Ryan K. The impact of severe asthama on patients' autonomy: A qualitative study. Health Expectations. 2019;22(3):528-36. DOI: http://dx.doi.org/10.1111/hex.12879.

27. Brown SL, Salmon P. Reconciling the theory and reality of shared decision-making: A "matching" approach to practitioner leadership. Health Expectations. 2019;22(3):275-83. DOI: http://dx.doi.org/10.1111/hex.12853.

28. Hanlon P, Gray CM, Chng NR, Mercer SW. Does Self-Determination Theory help explain the impact of social prescribing? A qualitative analysis of patients' experiences of the Glasgow 'Deep-End' Community Links Worker Intervention. Chronic Illness. 2019. DOI: http:// dx.doi.org/10.1177/1742395319845427. 